\title{
Los Come-muertos: the Grotesque Tale of Emigration
}

Roberta Giordano

University of Salerno, Spain

\begin{abstract}
The objective of this paper is to evaluate the key aspects of the "grotesque" interpretation proposed by José Rafael Pocaterra in Los Come-muertos for the theme of emigration. Pocaterra has traced an alternative route, probably deeper than it was made until that moment, rooted in the conviction that literature, necessarily realist, could, with satire and the distortion of human characteristics, not only lay bare human spirit, but above all, awake the dormant conscience of people.
\end{abstract}

[Keywords: Grotesque, Emigration, novel.]

"No; no es una historia de chacales, de hienas o de cuervos; no es, siquiera, una leyenda de necrófagos. Es apenas una relación corta, un poco triste, un poco pueril, donde hay infancia, el cielo brumoso de un diciembre provinciano, la carita triste de una niña que se pone a llorar" (Pocaterra 149).

"No; it is not a story of jackals, hyenas or crows, nor a legend of scavengers. It is just a short story, a little sad, a little childish, where there is childhood, the misty sky of a provincial December, the sad face of a child who starts crying" (Pocaterra 149).

It's a consolidated assumption that the Edgard Allan Poe's contribution represents a reference model for modern novel. According to the writer of Tales of the Grotesque and Arabesque this genre is the kind of prose that, more than the others, allows the author to show all his artistic ability, the only means which is able, together with poetry, to arouse a real form of internal exaltation, until he or she carries out a "formula" built around the idea that each work has to achieve an effect since the beginning, on the basis of which, the writer has to imagine the plot: the "unique effect" (Poe 106-107).

The English author also adds three other elements to this specific characteristics of the tale: the intensity and the end, both intrinsically connected with the "unique effect", and with the role covered by the epilogue, the solution offered to the enigma or to the conflict in the tale, and finally the extension that, although difficult to define, is represented by the author as a reading made all in one go, or that lasts a time from half an hour to two hours.

Although the comparison inevitable, the grotesque of Pocaterra is something different, because he never breaks down the human figure, or the natural aspect of things, just like Edgard Allan Poe had done before. He never aimed, therefore, at realizing an extra or superhuman literature, but he just used it to highlight and to ridicule some aspects of society:

"Pero para Poe lo grotesco y lo arabesco descomponen la figura humana y el aspecto natural de las cosas, hasta lograr una literatura extra o sobrehumana. En Un viaje a la luna lo grotesco es lo fantástico;

Rupkatha Journal on Interdisciplinary Studies in Humanities (ISSN 0975-2935), Vol 2, No 3, 2010

URL of the Issue: http://rupkatha.com/v2n3.php

URL of the article: http://rupkatha.com/V2/n3/LosComemuertos.pdf

(C) www.rupkatha.com 
en Morella es lo misterioso; en El retrato oval es lo ultra real; en Los anteojos es lo cruel; en El misterio del General Smith es lo mostruoso. Además el humorismo de Poe es como una mueca descarnada y misantrópica, rematada de sarcasmo. Pocaterra, que también tiene esta vena, es sin embargo más condensado y más poético (Tejera 157)."

[In Poe's works, the grotesque and the arabesque break up the human figure and the natural appearance of things to such an extent that an extra or super-human literature is derived. In The Balloon Hoax, the grotesque is the incredible; in Morella, the mysterious; in The oval portrait, the unreal; in The Magnifying glass, the cruelty; in The man that was used up the monstrosity. Also, the humor of Poe is a kind of hard-hearted and misanthropic grimace, full of sarcasm. On the other hand, Pocaterra, who also has this inclination, is more condensed and poetic in his works' (Tejera 157).]

Even if Tejera initially tries to compare Cuentos grotescos with the past experiments, the Esperpentos by Ramón María del Valle Inclán, Tragedias grotescas by Pío Baroja, and Tragedias grotescas by Rufino Blanco Fombona, and Tales grotesque and arabesque by Edgard Allan Poe, she finally concludes that there can't be any parallelism with them. She considers Pocaterra's grotesque a new experiment and pointed out four specific categories: the grotesque-diabolic, the grotesque-fantastic, the grotesqueridiculous/sublime, the grotesque-ugly.

An important contribution of Spanish-American literature to the grotesque is given by the tale Las noches en el Palacio de la Nunciatura, written by the Guatemalan Rafael Arévalo Martínez. It turns out to be a strange history when considered, in spite of the scarce fame, that it is a little masterpiece in this genre, and an authentic approximation to the absurdliterature, where men become animals, the objects come to life, where there are allusions to the homosexual world, and finally where very often life moves between spiritual and fantastic.

Wolfgang Kayser developed one of the most credible arguments on the gender. He strongly believed that the fundamental attribute of the grotesque was a distanced view of the world that, causing a feeling of complete alienation in humans, might lead to a radical subversion of values and relationships between the various elements of reality. In that way, the fantastic, the macabre, the monstrous, the eccentric, the obscene and the ridiculous burst into daily life, suddenly altering the laws governing the physical and psychological world, preferring settings almost always nightly, dark, grimly, inclined to the deformation of natural proportions, the loss of identity, in fact, absurd.

The grotesque, which, according to Kayser, appears as a disturbing mix of heterogeneous elements and paradoxical as beauty and horror, or sublime, vulgar and ridiculous, causing extreme reactions such as laughter and horror, would be nothing but a representation of the absurd, symptom and 
effect of the incomprehensibleness and inexplicability of reality, a sign of dull perception of the world, especially of a world of nonsense, or whose meaning escapes human comprehension.

Although the representation of the grotesque offered by Kayser is full of a sense of absurd, ultra-real and nocturnal, absent in Pocaterra, I think there are still other factors that combine the two visions, and I'm referring to the intellectual German idea that the use of grotesque has heightened at particular points in European history, especially at times of crisis such as the Renaissance, the Romanticism and the first half of the twentieth century, or even socio-economic transformation, which produced an alteration in the system of values and understanding of the world.

In fact, the phase marked by the development of the modernist trend in Hispano-America, to which you can properly connect the figure and the work of Arévalo Martínez, represented exactly one of those moments of crisis and profound change, characterized by the entrance of the Latin American continent in global capitalist system, from which a situation of complete exclusion arose for the writer by a society, now concerned only with the laws of the market. So the perception of his own inadequacy, and non-location with respect to the new situation of the company, led the writer to search into grotesque a tool to give vent to his creative force, and which represent the new condition, which resulted soon into a detached view of the world, a trend that could have been appreciated by authors such as Julián del Casal, Herrera y Reissig, Darío.

I think that the all existence of Pocaterra coincided with an exceptional season of transformation and crisis for Venezuela: it is a scenario of conflicting events, it is a country that replaces the old the new "caudillo", Gómez; it is a country that starts to experience the understanding of being rich, and despite the economic structure within a rigid and archaic, precapitalist style, the comparison with foreign oil giants; and it is, finally, a country that would have soon started to deal with the phenomenon of emigration.

In fact, if this phenomenon was limited in the first half of 1900, on the other hand, considering that Italy since 1903 participated with the United States, Britain and Germany to block the coast and ports of Venezuela, forcing the country to pay its large debts, it became very significant especially after the Second World War. This trend mainly sharpened as the Latin American country went into the oil economy, turning it in fact "en uno de los más amplios receptores de poblaciones inmigratorias Italianas en el Nuevo Mundo" (Franzina 429), and attracting, among others, many Italian workers, completely devoid of any prospect of life in post-war.

Literature would not remain impassive in the face of this epochal transformation that pushed Antonio Scocozza, emphasizing the fact that the criticism is unanimous in recognizing the forerunner of its kind in Daniel Mendoza, the author of the tale Un llanero en la capital (focusing on the meeting between the venezuelan capital man el doctori, and el campesino ${ }^{\mathrm{iii}}$ ), 
to propose a comparison between three interpretations offered to migration in Venezuela: first that of "costumbristas",iv, just like Mendoza, who would have filled, he said, the limits of a history still insufficient and a not yet ripe literature, contributing greatly to the knowledge of national history, of which migration was becoming one of the top themes (127).

Then, after a parenthesis on the writer who first gave the "emotional" dimension of emigration to the reader, namely Vicente Gerbasi, who by verses full of sweetness and expressiveness, masterfully describes the fate of his emigrant father (Gerbasi 70-71), Scocozza analyzes the position taken by Rómulo Gallegos in Los inmigrantes, where, after the phase "positivist", based on the idea that mestizaje ${ }^{v}$ is a factor of weakness for a people, an encouragement of ignorance and barbarism, now defends the idea that foreign contribution, mainly European, can be a growth factor, the argument of "desarraigo-arraigo-desarraigo"vi: the emigrant leaves to escape the misery of his homeland, and gives to the hosting country his work and his own blood, thus laying basis, through the children of this mixed generation for a better future (124).

Scocozza stresses that Pocaterra assumes a position diametrically opposed to that expressed by Gallegos, that is rooted in the belief that the backwardness of Venezuela derives from the excessive heterogeneity of the population, and developing so in Los Come-muertos a portrait, in many strong colors, on Italian presence in Venezuela, in which the grotesque describes the condition of misery in which this new slice of the population lives, cruelly denied.

As always, the wise and sarcastic use of tongue by Pocaterra is amazing, the words are measured, carefully chosen, so that the reader reaches the plastic, as well as the sensory dimension of the narration, which in this case has the taste of despair. The Giuseppe's, for example, who made of the father's name their surname, to represent the feeling of identity and unity that binds them together, are called by the children of the neighborhood "Come-muertos", a nickname that on the one hand represents a tendency of Venezuelan Spanish, that is, to use often compound words, and neologisms, however, implied in his hyperbolic trend, on the other hand it is functional to a macabre representation of those lives:

Los Giuseppe eran una familia calabresa, hambrienta, desarrapada y sucia que vivían en un rincón de tierra, en una cabaña hecha de pedazos de palo, de duelas, de restos de urnas robados en el Cementerio de Morillo, una de cuyas tapias derruídas lindaba con la vivienda de los Giuseppe, si es que puede llamarse vivienda un cacho de tierra colorada, diez o doce matas de cambur, un mango, y bajo el mango los techos de la zahurda de latas y piedras, y bajo la casa, la familia: dos muchachos como hechos a hachazos, con los brazos muy largos y las manos muy grandes y los pies enormes. Rojos, de pelambre erizada como los pelos de los gatos monteses y que ayudaban al viejo en trabajos de mozo de cuerda en la ciudad a veces, 
y a veces en el merodeo de los corrales. Además, una chica rubia, también pecosa y peli-roja, con nombre lindo de princesa: Mafalda. Cuatro cacharros, hambre, vagancia, fealdad del paisaje, de los habitadores, del concepto mismo que tenía la ciudad hacia aquel torpe rincón de cementerio donde vivían unos italianos que comían muertos (Pocaterra 149-150).

[Giuseppe's family is from Calabria, hungry, poor and dirty, living in a small piece of land, in a wood hut, made of remains of ballot boxes stolen from the cemetery of Morillo, of which one destroyed wall bordering the Giuseppe's house, if you can call home a piece of colored earth, ten or twelve Cambur vii and one mango tree, under which there is the roof of the pigsty made with tinplates and stones, and inside the house the family: two children as deformed, with very long arms and large hands and huge feet. They are red-head, with shaggy mop hair like the coat of wildcats, and help their father in his job as porter in the city and in its outskirts. In addition, a fair skinned freckled child with red hair and named like a princess: Mafalda. Four derelicts, hunger, vagrancy, ugliness of the landscape and its inhabitants, of the concept itself the citizens had about that horrible piece of the cemetery, where lived some Italians eating the dead (Pocaterra 149-150).

The pitiless realism of the author finds in the grotesque genre an exceptional instrument of expression: ("Dos muchachos como hechos a hachazos, con los brazos muy largos y las manos muy grandes, y los pies enormes"), where the harshness of those lives matches the harshness of bodies ("Rojos de pelambre erizada como los pelos de los gatos monteses"), and towards which Pocaterra demonstrates his "pietas": ("una chica rubia, también pecosa y peliroja, con nombre lindo de princesa: Mafalda"). The Giuseppe's are poor, very poor indeed, so that the father was forced to steal some hens from the yard of the sisters, Las Hermanitas de los Pobres: note that, also in this case, the linguistic component is an essential support in the plot, even the name of religious order tends to remember, to emphasize, almost obsessively, the condition of despair that grips this world.

The scene depicting the arrest of Giuseppe, for having committed the theft, is constructed with masterful detail, again by a language, that powerful, turns man's clothing into the tool of symbolic representation of his shame, shame, not so much to have stolen, but for being unable to offer a better future for his family:

Un día, Giuseppe padre fue arrestado. Parece que se desaparecieron unas gallinas muy gordas del corral de las Hermanitas de los Pobres; qué sé yo...Lo vimos desfilar, amarrado por las muñecas, feroz y sombrío, entre dos agentes que le empujaban, brutales, calle abajo. Tenía el traje más desgarrado que de costumbre y marchaba cabizbajo, tambaleante, avergonzado probablemente de su horrible delito, con las faldas de la camisa por fuera, al extremo de un eterno 
chaleco de casimir viii indefinible que usaba a manera de chaqueta (Pocaterra 150-151).

[One day, Giuseppe was arrested. Some very fat chickens had disappeared from the yard of Hermanitas de los Pobres, what I know... we saw him leave, tied at the wrists, fierce and melancholic, between two policemen pushing him brutally down the road. He was wearing a dress ruined more than usual, and walked with his head down, staggering, probably ashamed of his terrible crime, with the shirt outside his pants under an indestructible and shapeless cashmere (casimir $^{\text {viii }}$ ) waistcoat as jacket (Pocaterra 150-151).]

The act of the children reflects the complexity and contradictions of the adult world, like them, in fact, they can be cynical, ruthless, cruel, so to arrange a fight with stones against the young "Come-muertos":

"Juío...Juíoix, Come-muerto!" (Pocaterra 151),

"Jew...Jew, dead eating!" (Pocaterra 151),

But they can be also brave and proud, like the young Giuseppe's, defying the danger to defend their mother and younger sister.

"No obstante, nos tenían a raya. Sus pedradas, certeras, furiosas, pasaban zumbando por nuestros oídos. Otras dos bajas: uno que gritó al lado mío poniéndose ambas manos sobre un ojo, otro que saltaba en una sola pierna, cogiéndose el pie aporreado en lo alto del muslo: ¡Ay, carrizo, ayayay, carrizo!" (Pocaterra 152).

"Nevertheless, they kept us at distance. Their firm and furious stones passed hissing. Two other stones more closer: one shouted at my side putting both hands on the eye, and another jumping around holding his foot: ¡Ay, carrizo, ayayay, carrizo!"” (Pocaterra 152).

¡Ay, carrizo, ayayay, carrizo!" (Pocaterra 152).

The scene of the clash is almost cinematic:

"Tú, que te metas por el cementerio y los cojas de atrás pa alante!" (Pocaterra 152),

["you, go to the cemetery and stab them in the back!" (Pocaterra 152)];

the language used to describe it betrays violence:

"Sin vacilar, los ojos inyectados de ira y los bolsillos repletos de piedras, trepé la tapia, y con un guarataro ${ }^{\mathrm{xi}}$ en cada mano, por entre las tumbas viejísimas, de ahora un siglo, y los montículos cubiertos de ásperos cujíes y las cruces de madera podrida avancé, cauteloso, con todo el instinto malvado de la asechanza, en plena alevosía de pequeña alimaña feroz" (Pocaterra 152).

"Without hesitation, with eyes full of anger and pockets full of stones, I climbed the wall, and with a guarataro ${ }^{\mathrm{xi}}$ in each hand, through the old 
graves, the hills covered with wild cujíes ${ }^{\mathrm{xii}}$ and the crosses of rotten wood, I advanced cautiously, with all the bad instincts of deception and with the perfidy of a small fierce beast" (Pocaterra 152).

However, suddenly, the cruelty of this image will be replaced by the tenderness of the man (Pocaterra's alter ego), who repents bitterly about the absurdity of these actions:

"Sobre un montículo cubierto de yerbajos, una fosa sin duda, estaba Mafalda, la peli-roja. Tenía la frente abierta por un golpe horrible, y un hilillo de sangre iba desde la sien hasta la hierba, trazando un caminito rojo, muy delgado; era como la cinta encarnada del rabo de los papagayos" (Pocaterra 152).

["On a mound covered with weeds, certainly a grave, there was Mafalda, the redhead child. Her forehead was hurt by a terrible blow, and a little trickle of blood was running from his temple to the grass, marking a small red course, very thin, like a red-colored tape on the tail of parrots" (Pocaterra 152).]

"Y arrodillada, se arrastraba a mis pies, las mechas en desorden, semejante a una gran trágica, con todo el pelo rojo como una llamarada" (Pocaterra 153).

["On her knees she was dragging herself toward my feet, the tufts in a mess, like a great tragedy actress, with the hair like a flame" (Pocaterra 153).]

"En la tapia, al saltar, apoyando sus manecitas en mis hombros, acercó a mí su carita pecosa, sucia, con la frente vendada y sangrienta. Todavía recuerdo aquella expresión de sus ojos amarillentos que tenían la dulzura de la tarde amarilla sobre las tumbas" (Pocaterra 153-154).

["Jumping on the wall, resting her little hands on my shoulders, She moved to me her freckled little face, dirty, with his head bandaged and bloody. I can still remember that look in her yellowish eyes, which had the sweetness of the yellow evening over the graves" (Pocaterra 153154).]

The sentences above are a condensation of Pocaterras' world: there are, in fact, all the appeals of his own writing style (the extreme adjectives, the constant recourse to the diminutives, the use of compound words, the figured description derived from the purest Venezuela Spanish), which actually tend to emphasize more the emotional dimension, than the meaning of expressions.

Those words also serve to give the exact scope not only of the writer, but also of the man. He feels the social and political responsibility of literature: the shame for the infamy committed, and the relief provided to the child, and therefore the meeting between the Venezuelan and the foreigner must necessarily be interpreted as a sign of a newborn moral and cultural 
consciousness, aimed at overcoming the final rejection of the "other". Pocaterra so convinces the reader that he narrated an incident that had happened when he was very young, the reason of which he cannot explain, but it finally allowed him to understand the weak:

"Yo no supe cómo explicar en casa por qué tenía las manos y el traje manchados de sangre. No lo supe explicar entonces. Hoy tampoco podría hacerlo" (Pocaterra 154).

["Back home, I could not explain why my hands and clothes were stained. I was not able to do this at that time. But I still can't do that" (Pocaterra 154).]

\section{Notes}

${ }^{i}$ All the translations by the author.

ii 'doctor' is the learned man of the city.

iii 'campesino' is the countryman.

iv costumbrista derives from costumbrismo, that is the Spanish and Latin American literary movement that produced works celebrating the customs and folkways.

${ }^{v}$ mestizaje stands for multiracial

${ }^{\text {vi }}$ desarraigo-arraigo-desarraigo: leave one's country-settle down- leave one's country.

vii Cambur is a word indicating the plant of banana.

viii The word casimir is a typical example of a foreign word, from the french cachemire, transcribed by Pocaterra in a deliberately wrong way.

${ }^{i x}$ One of the most common characteristics of the phonetic system of America's Spanish is the

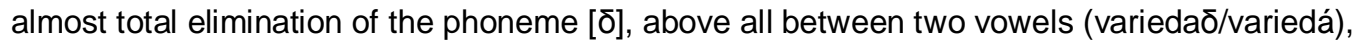
or in the word's end.

${ }^{x}$ Carrizo is a venezuelan euphemistic expression indicating disgust, surprise, refusal or admiration, more or less corresponds to the word damn.

${ }^{x i}$ Guarataro is a native word indicating a white colored and compact granite stone.

xii Cuji is the venezuelan common name of various Mimosaceae plants with thorns, growing in hot and humid places.

\section{Works cited}

Acevedo, Ramón Luis. "Lo grotesco y lo absurdo en Las noches en el Palacio de la Nunciatura de Rafael Arévalo Martínez", Studi di Letteratura ispanoamericana, 17. Milano: 1986. Print

Albonico, Aldo. L'America Latina e l'Italia. Roma: Bulzoni, 1984. Print Poe, Edgard Allan. The Complete Works, XI. New York: AMS, 1965. Print

Alvar, Manuel. Manual de dialectología hispánica: el español de América. Barcellona: Ariel, 1996. Print.

Alvarado, Lisandro. Glosario de voces indígenas de Venezuela. Caracas: Ministerio de Educación, Dirección de cultura y bellas artes, 1953. Print

Diccionario de venezolanismos. Caracas, Universidad Central de Venezuela, 1993. Print

Fowler, Alastair. Kinds of Literature. An Introduction to the Theory of Genres and Modes. Harvard: Harvard University Press, 1982. Print 
Franzina, Emilio. Gli italiani al Nuovo Mondo. Milano: Mondadori, 1995. Print

Gerbasi, Vicente. Mi padre, el emigrante, in Obra Poética. Caracas: Biblioteca Ayacucho, 1986. Print

Kayser, Wolfgang. Das Groteske, seine Gestaltung in Malerei und Dichtung. Oldenburg: Stalling, 1957. Print

---. Interpretación y análisis de la obra literaria. Madrid: Edit. Gredos, 1960. Print Lipski, John M. El español de América. Madrid: Anaya, 2004. Print

López Morales, Humberto. La aventura del español en América. Madrid: Espasa, 2005. Print Mora, Gabriel. En torno al Cuento: de la teoría general y de su práctica en Hispanoamérica. Madrid: Ediciones José Porrúa Turanzas, S.A., 1985. Print

Pocaterra, José Rafael. Cuentos grotescos. Caracas: Monte Ávila Editores, 1972. Print

Rosemblat, Ángel. Estudio sobre el habla de Venezuela, Buenas y malas palabras. Caracas: Monte Ávila Editores, 1984. Print

Scocozza, Antonio. "El emigrante italiano en el cuento venezolano", in Ideología y ficción en el siglo XX, II Congreso internacional de literatura y política en América Latina. Caracas: Ediciones La Casa de Bello, 1998. Print

Tejera, María Josefina. José Rafael Pocaterra. Ficción y denuncia. Caracas: Monte Ávila Editores, 1976. Print

René Wellek, Austin Warren. Theory of Literature. New York: Harcourt, 1956. Print

Roberta Giordano is a postdoctoral researcher at the Political Sciences Faculty of the University of Salerno. Email: giordanorob@yahoo.it 